\title{
THE TRANSPORT OF SPERMATOZOA IN SPAYED EWES: A COMPARISON OF TWO METHODS OF STEROID ADMINISTRATION
}

\author{
A. J. ALLISON \\ Invermay Agricultural Research Centre, \\ Private Bag, Mosgiel, New Zealand \\ (Received 25th April 1972, accepted 13th June 1972)
}

The transport of spermatozoa in spayed ewes is grossly impaired in comparison with that observed in entire animals (Allison, 1972). Although hormonal replacement regimens used resulted in a behavioural oestrus of similar duration to that recorded in entire ewes, the physiological state of the uterus was not maintained. These differences could be a result of the pattern of steroid release following single intramuscular injections. In particular, the pattern of oestrogen release following a single intramuscular injection is unlikely to resemble the patterns recorded in the entire ewe before and about the time of oestrus (Moore, Barrett, Brown, Schindler, Smith \& Smyth, 1969; Smith \& Robinson 1970). If the release of steroids in entire ewes could be reproduced precisely by intravenous infusion, normal transport of spermatozoa might be attainable in spayed ewes. The aim of the present work was to test this hypothesis.

Thirty-two ovariectomized Merino ewes were used in the experiment. Sixteen ewes received intramuscular injections (Allison, 1972) and sixteen were given progesterone and oestrogen by intravenous infusion. Ewes were slaughtered 2 or $24 \mathrm{hr}$ after insemination.

Ewes receiving injections were given $10 \mathrm{mg}$ progesterone per day for 12 days followed by a single injection of $25 \mu \mathrm{g}$ oestradiol benzoate (ODB) $48 \mathrm{hr}$ after the last progesterone injection.

Ewes receiving infusions were restrained in metabolism cages, steroid hormones being continuously infused into the jugular vein in $0.9 \%$ saline. Progesterone and oestrogen were dissolved in alcohol $(1 \mathrm{mg} / \mathrm{ml}$ and $1 \mu \mathrm{g} / \mathrm{ml}$, respectively) before they were added to the saline. Progesterone stayed in solution but ODB formed a micro-fine colloidal suspension.

Polythene catheters 12 in. long, i.d. 0.015 in. (Intracath 1819, Bard-Davol, England) were inserted through a 19-gauge needle and passed caudally to a depth of approximately 8 in. The external portion of the catheter, the 19-gauge needle and the solution administration set ( 41 T. Baxter, D.H.A. Sydney) were sutured to the skin. An additional suture on the shoulders of the animal ensured freedom of movement without undue stress on the catheter.

Infusion bottles were changed every $12 \mathrm{hr}$ when ewes were on progesterone infusions and every $6 \mathrm{hr}$ during the period of oestrogen treatment. Approxi- 
mately $30 \mathrm{~min}$ before the change-over time, volumes infused in the preceding $11 \frac{1}{2}$ (or $\left.5 \frac{1}{2}\right) \mathrm{hr}$ were recorded. The amount of hormone which would give the required dose in the ensuing 12 (or 6) hr, providing the infusion rate remained constant, was then calculated. This approach was more accurate and less timeconsuming than controlling infusion rates by adjustment of the flow-control clamp on the solution administration set. All infusion bottles were thoroughly washed and heat-sterilized before use.

The intended pattern of infusion of progesterone and ODB was based on the data of Moore et al. (1969) and Smith \& Robinson (1969, 1970). Progesterone was infused over a 12-day period and ewes received approximately $25 \mu \mathrm{g}$ ODB over the $60-\mathrm{hr}$ infusion period, although those animals slaughtered $2 \mathrm{hr}$ after

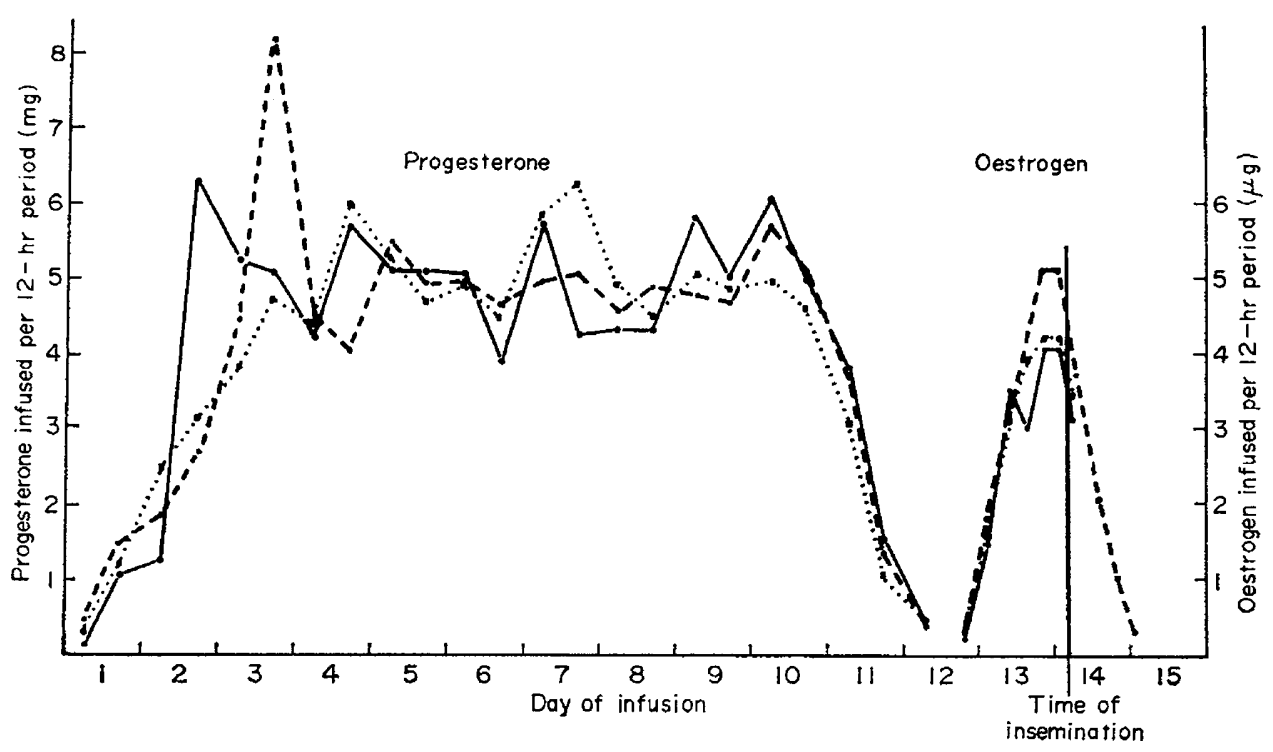

TEXT-FIG. 1. Levels of progesterone and oestrogen infused into ovariectomized Merino ewes. Curves shown for three ewes.

insemination would have received less than this amount (see Text-fig. 1). Infusion rates varied somewhat due to indefinable factors; typical curves for three ewes are presented in Text-fig. 1.

It was not possible to detect oestrus in ewes receiving infusions. These animals were artificially inseminated $6 \mathrm{hr}$ after the maximum rate of infusion of ODB (see Text-fig. 1). Ewes which were injected were inseminated $24 \mathrm{hr}$ after receiving ODB.

Semen was collected from three rams and ewes were inseminated with $0 \cdot 15$ $\mathrm{ml}$ of the pooled ejaculate. This procedure has been shown to result in a total population of spermatozoa within the cervix comparable with that achieved following natural mating (Allison, 1972). Ewes were slaughtered 2 or $24 \mathrm{hr}$ after insemination. Techniques for slaughter, recovery of spermatozoa from the vagina, cervix, uterus and Fallopian tubes and methods of estimation of total numbers of spermatozoa have been reported previously (Allison, 1972; Allison 
\& Robinson, 1972). Analysis of variance was conducted on the estimated numbers (plus 2 to deal with zero values) after log transformation.

Estimated mean numbers of spermatozoa are shown in Table 1. The numbers of spermatozoa recovered were low in comparison with those recorded in entire ewes (Allison, 1972; Mattner \& Braden, 1963). Numbers of spermatozoa recovered from the vagina and cervix were higher at $2 \mathrm{hr}$ than at $24 \mathrm{hr}$ after insemination $(P<0.01)$, and more spermatozoa were recovered from the caudal cervix than from the mid- and cranial thirds, respectively $(P<0.01)$. Numbers recovered from infused ewes were generally higher than those recovered from

TABLE 1

ESTIMATED MEAN NUMBERS OF SPERMATOZOA RECOVERED FROM VARIOUS DIVISIONS OF THE GENITAL TRACT OF EWES

\begin{tabular}{|c|c|c|c|c|c|c|c|}
\hline \multirow{3}{*}{$\begin{array}{l}\text { Route of hormone } \\
\text { administration }\end{array}$} & \multirow{3}{*}{$\begin{array}{c}\text { Time of } \\
\text { slaughter } \\
(\text { hr })\end{array}$} & \multicolumn{6}{|c|}{ Site of recovery of spermatozoa } \\
\hline & & \multirow[b]{2}{*}{ Vagina } & \multicolumn{4}{|c|}{ Cervix } & \multirow[b]{2}{*}{ Uterus* } \\
\hline & & & Caudal & Mid & Cranial & Total & \\
\hline \multirow[t]{2}{*}{$\begin{array}{l}\text { A. ARITHMETIC MEANS } \\
\text { Intravenous infusion }\end{array}$} & $\begin{array}{r}2 \\
24\end{array}$ & $\begin{array}{r}20151 \\
196\end{array}$ & $\begin{array}{r}5574 \\
83\end{array}$ & $\begin{array}{r}2709 \\
132\end{array}$ & $\begin{array}{r}425 \\
31\end{array}$ & $\begin{array}{r}8708 \\
246\end{array}$ & $\begin{array}{ll}1 \cdot 31 & (8) \\
2 \cdot 23 & (4)\end{array}$ \\
\hline & Total & 20347 & 5657 & 2841 & 456 & 8954 & 3.54 \\
\hline \multirow[t]{2}{*}{ Injection } & $\begin{array}{r}2 \\
24\end{array}$ & $\begin{array}{r}9054 \\
30\end{array}$ & $\begin{array}{r}1570 \\
100\end{array}$ & $\begin{array}{l}333 \\
186\end{array}$ & $\begin{array}{l}15 \\
63\end{array}$ & $\begin{array}{r}1918 \\
349\end{array}$ & $\begin{array}{ll}0 \cdot 57 & (3) \\
2 \cdot 47 & (4)\end{array}$ \\
\hline & Total & 9084 & 1670 & 519 & 78 & 2267 & $3 \cdot 04$ \\
\hline \multicolumn{8}{|c|}{$\begin{array}{l}\text { B. GoRRECTED (LOGARITHMIC) } \\
\text { MEANS }{ }^{-1}\end{array}$} \\
\hline \multirow[t]{2}{*}{ Intravenous infusion } & 24 & $\begin{array}{r}10520 \\
195\end{array}$ & $\begin{array}{r}3837 \\
41\end{array}$ & $\begin{array}{r}676 \\
41\end{array}$ & $\begin{array}{r}23 \\
2\end{array}$ & $\begin{array}{r}4536 \\
84\end{array}$ & $\begin{array}{l}0.98(8) \\
0.06(4)\end{array}$ \\
\hline & Total & 10715 & 3878 & 717 & 25 & 4620 & $1 \cdot 04$ \\
\hline \multirow[t]{2}{*}{ Injection } & $\begin{array}{r}2 \\
24\end{array}$ & $\begin{array}{r}2046 \\
21\end{array}$ & $\begin{array}{r}955 \\
7\end{array}$ & $\begin{array}{r}116 \\
2\end{array}$ & $\begin{array}{l}6 \\
1\end{array}$ & $\begin{array}{r}1077 \\
10\end{array}$ & $\begin{array}{l}0.02(3) \\
0.06(4)\end{array}$ \\
\hline & Total & 2067 & 962 & 118 & 7 & 1087 & 0.08 \\
\hline
\end{tabular}

Number of spermatozoa recovered expressed as a Mean $\times 10^{3}(n=8)$.

* Number of ewes from which spermatozoa were recovered in parentheses.

$\dagger$ Arithmetic values derived from reconversion of mean log values of individual data.

injected ewes, although differences did not reach significance at the $5 \%$ level (vagina, $P<0 \cdot 10$; cervix $P<0 \cdot 10$ ).

All ewes receiving infusions, were found to have spermatozoa in the uterus $2 \mathrm{hr}$ after insemination compared with only three of eight ewes receiving injections. There was no difference in the incidence of recovery $24 \mathrm{hr}$ after insemination. Spermatozoa were recovered from the Fallopian tubes of nine ewes only: six of the ewes receiving infusions and three of those receiving injections, respectively.

Intravenous administration of progesterone and ODB in a pattern intended to resemble the steroid release of a normal cycle resulted in some improvement in the efficiency of sperm transport. This improvement was not great, however, and the pattern of distribution and maintenance within the reproductive tract 
was still grossly impaired in relation to that observed in entire animals (Allison, 1972).

\section{REFERENCES}

AlLison, A. J. (1972) A comparison of the transport of spermatozoa in spayed and entire ewes. $\mathcal{F}$. Reprod. Fert. 31, (3) (in press).

AlLison, A.J. \& Robinson, T.J. (1972) The recovery of spermatozoa from the reproductive tract of the spayed ewe treated with progesterone and oestrogen. F. Reprod. Fert. 31, 215.

MATtNER, P. E. \& BRADEN, A. W. H. (1963) Spermatozoa in the genital tract of the ewe. 1. Rapidity of transport. Aust. F. biol. Sci. 16, 473.

Moore, N. W., Barrett, S., Brown, J. B., Schindler, I., Smrth, M. A. \& Smyth, B. (1969) Oestrogen and progesterone content of ovarian vein blood of the ewe during the oestrous cycle. 7 . Endocr. $44,55$.

Smith, J. F. \& Robinson, T. J. (1969) Luteal function in the Merino ewe and the effect of exogenous progestagen. F. Endocr. 44, 79.

SMITH, J. F. \& RoBinson, T. J. (1970) The effect of exogenous progestagen on ovarian vein plasma levels of free oestrogens in the Merino ewe. F. Endocr. 48, 485. 